\title{
Challenges and Development of Tin-Based Anode with High Volumetric Capacity for Li-lon Batteries
}

\author{
Fengxia $\operatorname{Xin}^{1}$ D $\cdot$ M. Stanley Whittingham ${ }^{1}$ D
}

Received: 15 May 2020 / Revised: 21 July 2020 / Accepted: 5 September 2020

(c) The Author(s) 2020

\begin{abstract}
The ever-increasing energy density needs for the mass deployment of electric vehicles bring challenges to batteries. Graphitic carbon must be replaced with a higher-capacity material for any significant advancement in the energy storage capability. Sn-based materials are strong candidates as the anode for the next-generation lithium-ion batteries due to their higher volumetric capacity and relatively low working potential. However, the volume change of Sn upon the Li insertion and extraction process results in a rapid deterioration in the capacity on cycling. Substantial effort has been made in the development of Sn-based materials. A SnCo alloy has been used, but is not economically viable. To minimize the use of Co, a series of $\mathrm{Sn}-\mathrm{Fe}-\mathrm{C}, \mathrm{Sn}_{y} \mathrm{Fe}, \mathrm{Sn}-\mathrm{C}$ composites with excellent capacity retention and rate capability has been investigated. They show the proof of principle that alloys can achieve Coulombic efficiency of over $99.95 \%$ after the first few cycles. However, the initial Coulombic efficiency needs improvement. The development and application of tin-based materials in LIBs also provide useful guidelines for sodium-ion batteries, potassium-ion batteries, magnesium-ion batteries and calcium-ion batteries.
\end{abstract}

Keywords Li-ion batteries $\cdot$ Tin-based anode $\cdot \mathrm{Sn}-\mathrm{Fe}-(\mathrm{C}) \cdot$ High volumetric capacity

\section{Introduction}

Lithium-ion batteries, over the last 40 years, have successfully taken over in turn portable electronics, then electric vehicles (BEVs), plug-in hybrid electric vehicles (PHEVs) and hybrid electric vehicles (HEVs) and now large-scale grid storage due to their high energy density and long cycle life [1-5]. In awarding the 2019 Nobel Prize, the Nobel committee claimed "They (John B. Goodenough, M. Stanley Whittingham, Akira Yoshino) created a rechargeable world." In the global electric vehicle market, it is expected to exceed more than USD 151.6 billion by 2024 at a compound annual growth rate (CAGR) of $11.0 \%$ [6]. Unit sales are anticipated to reach 97 million vehicles worldwide by 2025 [7]. A major factor behind

The author, Prof. Stanley Whittingham, was awarded the Nobel Prize in Chemistry in 2019. His perspective article is very important to promote EER.

M. Stanley Whittingham

stanwhit@gmail.com

1 Chemistry and Materials, Binghamton University, Binghamton, NY 13902-6000, USA the growth of electric vehicles is that various governmental agencies are encouraging the sale of these vehicles, which could solve the negative effect of climate change along with alarming pollution. The ever-increasing energy density needs for mass deployment of EVs to replace the majority of gasoline powered transportation bring challenges to batteries.

Oxides are the predominant cathode material in Li-ion batteries used for vehicular propulsion in 2020. BMW is using lithium-nickel-manganese-cobalt oxide (NMC) in their electric cars, and Tesla's electric vehicle battery cathodes are lithium-nickel-cobalt-aluminum oxide (NCA). Nissan Leaf adopts their positive materials from lithium-manganese oxide (LMO) to NMC, which largely increased energy density. Chevrolet Bolt EV and Ford Focus also use oxide cathodes. $\mathrm{LiFePO}_{4}$ is the preferred cathode material in China. In all these cases, the dominant anode is a carbonaceous material, which has a very low theoretical volumetric capacity, $747 \mathrm{Ah} \mathrm{L}^{-1}$, taking up essentially half the volume of the cell. Thus, for any significant advancement in the energy storage capability, the carbon must be replaced with some other higher-capacity material. Ideally, lithium metal could be used with a capacity of $3860 \mathrm{Ah} \mathrm{kg}^{-1}$ and $2062 \mathrm{Ah} \mathrm{L}^{-1}$ [8,9], but the 
use of Li metal has been limited by the formation and growth of Li dendrites as well as loss due to side reactions with the electrolyte. No safe solution has been found in the past 50 years. There have been various attempts to suppress the Li dendrites, including electrolyte modification (electrolyte additives, solid state electrolytes, etc.), membrane modification and lithium metal modification (the artificial SEI, the lithiophilic matrix, the conductive matrix, etc.). An alternative lithium container host to carbon must be found before a solution is found. Silicon and tin are the favorite candidates, and both are being extensively studied, as each of these can react with over four $\mathrm{Li}$ ions per $\mathrm{Si}$ or $\mathrm{Sn}$, achieving capacities essentially the same as that of pure lithium, $2000 \mathrm{Ah} \mathrm{L}^{-1}$. As shown in Fig. 1, the volumetric capacity of just $2 \mathrm{Li} / \mathrm{Sn}$ is more than double that of carbon [10]. However, both Sn and $\mathrm{Si}$ expand around $300 \%$ on reaction with $\mathrm{Li}$, damaging the electrode structure resulting in capacity fading. Some commercial battery carbon anodes have small amounts of silicon, boosting their performance slightly. In this review, we will focus on Sn-based materials as anodes in lithiumion batteries.

\section{Tin Lithiation Mechanism and Volume Expansion}

$\mathrm{Li}_{2} \mathrm{Sn}_{5}, \mathrm{LiSn}, \mathrm{Li}_{7} \mathrm{Sn}_{3}, \mathrm{Li}_{5} \mathrm{Sn}_{2}, \mathrm{Li}_{13} \mathrm{Sn}_{5}, \mathrm{Li}_{7} \mathrm{Sn}_{2}$ and $\mathrm{Li}_{22} \mathrm{Sn}_{5}$ (or $\mathrm{Li}_{17} \mathrm{Sn}_{4}$ ) phases at 415 and $25{ }^{\circ} \mathrm{C}$ were determined by coulometric titrations in Huggins' group [11, 12]. These results were consistent with the Li-Sn phase diagram. The calculated and experimental voltage profile from a tin negative electrode material in Dahn's work [13] shows that the theoretical electrochemical voltage profile compared well with experiment for $x<2.5$ in $\mathrm{Li}_{y} \mathrm{Sn}$, which matched well with formation of the bulk $\mathrm{Li}-\mathrm{Sn}$ alloy phases $\mathrm{Li}_{2} \mathrm{Sn}_{5}$ and LiSn [14]. For $y>2.5$, the equilibrium structures predicted by the phase diagram were not easily formed in an electrochemical cell at room temperature, which may be due to low atom mobility at room temperature originating from the high melting point of the Li-rich phase [15]. Zhang et al. [16] introduced elastic strain energy into the calculated electrochemical voltage, suggesting that in selective equilibrium $(y>2.33)$, the thermodynamic driving force was not enough to promote nucleation of the new equilibrium phase due to the elastically constrained conditions.

The volume change from tin to fully lithiated tin $\left(\mathrm{Li}_{4.4} \mathrm{Sn}\right)$ approaches $260 \%$ based on the densities of bulk tin and $\mathrm{Li}_{22} \mathrm{Sn}_{5}[17,18]$. During the lithiation and delithiation process, one $\mathrm{Li}-\mathrm{Sn}$ phase grows at the expense of another, and the difference in lattice parameters and structure between the two neighboring $\mathrm{Li}-\mathrm{Sn}$ alloys will cause accumulation and release of stress [19], which may cause particles to crack and

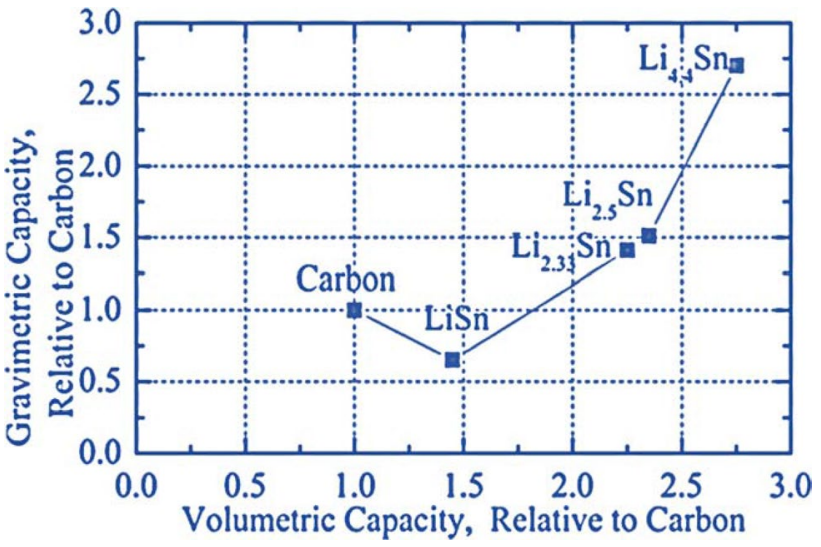

Fig. 1 Capacity of tin relative to carbon. Reproduced with permission from Ref. [10]. Copyright 2011, IOP Publishing Ltd.

SEI reformation, potentially losing the connection with the current collector, then failure of the electrode, resulting in a rapid deterioration in the cycling [20]. Substantial effort has been made to overcome these problems, including the design and exploration of different $\mathrm{Sn}$-based compounds with variable morphology (sizes, shapes, textures, porosity, etc.).

\section{Tin-Based Anode Materials}

\subsection{Sn Oxide Glass and Other Sn-Based Oxide}

In 1997, Fujifilm Celltec Co., Ltd., announced its Stalion battery using tin-based amorphous oxide containing $\mathrm{Sn}-\mathrm{O}$ as the active center for lithium insertion and other glass-forming elements [21], which could provide a gravimetric capacity of $>600 \mathrm{mAh} \mathrm{g}^{-1}$, corresponding to more than $2200 \mathrm{Ah} \mathrm{L}^{-1}$. This finding caused many researchers, who had been focused on improved carbonaceous anodes since Sony Company commercialized carbon in 1990, to switch to alternative materials. Idota et al. [22] obtained around 200 patents surrounding the Fuji cell, describing the preparation process and electrochemical performance on tin, other group IV elements, oxides and oxide composite glasses. Dahn et al. [14, 23] studied the electrochemical performance and structure change of the reaction of lithium with different tin oxide glasses, which demonstrated significant irreversible capacity loss ranging from 200 to $700 \mathrm{mAh} \mathrm{g}^{-1}$ in the first cycle. The original materials do not reform after lithium removal, and amorphous inactive lithium oxide is formed. The rate of Sn aggregation in the glass heavily depends on the cycling voltage range and the spectator/the $\mathrm{Sn}$ ratio and the temperature at which the cells were cycled. Over the years, various Sn-based oxides or Sn-based oxide glasses were reported with high capacities, good cycling and rate performance. However, 
they failed to be commercialized because of the high irreversible capacity loss in the first cycle, particularly in the case of tin oxides, where electrochemically inactive $\mathrm{Li}_{2} \mathrm{O}$ is formed.

\subsection{Sony's Sn-Co-C Alloy}

In European patent application, Kawakami and Asao had an extensive body of work on $\mathrm{Sn}-\mathrm{Co}-$ metal [24]. They showed that the Sn-Co alloy with the most disordered structures had the longest life. In 2005, Sony released their new Nexelion 14430-sized battery containing a nanostructured $\mathrm{Sn}-\mathrm{Co}-\mathrm{C}$-based negative electrode and claimed that the lithium-ion storage volumetric capacity was increased more than $30 \%$ over conventional lithium-ion batteries. Fan et al. [25] showed that Sony's amorphous tin electrode comprised 5-nm primary particles with a 1:1 tin-to-cobalt ratio and about 5\% titanium; these were aggregated into $1-\mu \mathrm{m}$ secondary particles (Fig. 2). The pair distribution function (PDF) method, which directly probes a local atomic-scale structure by examining atomic correlations, gave the answer that the local ordering of Sony's SnCo was similar to that of crystalline SnCo. This material could be described as a nanocrystalline $\mathrm{Sn}-\mathrm{Co}$ stabilized by $\mathrm{C}$ and $\mathrm{Ti}$. The discharge and charge curves of Sony's SnCo anodes are characteristic of single-phase behavior. A discharge capacity of 550 $\mathrm{mAh} \mathrm{g}^{-1}$ was obtained in the first cycle, corresponding to an irreversible capacity loss of $150 \mathrm{mAh} \mathrm{g}^{-1}$, which reached about $25 \%$ of the whole capacity. The electrode stabilized at $400 \mathrm{mAh} \mathrm{g}^{-1}$ for 30 cycles at $0.5 \mathrm{~mA} \mathrm{~cm}{ }^{-2}$, which was much superior than crystalline SnCo and Sn. Dahn et al. also tested the cycling performance of a commercial $14430 \mathrm{Nex}$ elion cell from a Sony battery pack [26]. They used a 1C charge/discharge rate for the first 30 cycles, and the battery was charged at $\sim \mathrm{C} / 3$ and discharged at $\sim 1 \mathrm{C}$ for the 30 to the 375 th cycles and at a $\sim \mathrm{C} / 3$ rate for the rest 225 cycles. After 600 cycles, the capacity was still above $600 \mathrm{mAh}$. However, the high price and toxicity of Co did not allow market penetration beyond the initial camcorder application.

\subsection{Sn-Fe-(C) System}

Encouraged by the success of Sony's Sn-Co-C anode, research focused on $\mathrm{Sn}-\mathrm{M}$ (M is the inactive metal) materials, such as $\mathrm{Sn}-\mathrm{Cu}$ alloy, $\mathrm{Sn}-\mathrm{Ni}$ alloy, $\mathrm{Sn}-\mathrm{Fe}$ alloy and $\mathrm{Sn}-\mathrm{Co}$ alloy. The introduction of the electrochemically inactive metal $\mathrm{M}$ serves as a sink to hold the tin so that it is less reactive with the electrolyte than free tin metal. A carbon coating further protects the $\mathrm{Sn}-\mathrm{M}$ compounds from side reactions. The reaction equation for $\mathrm{Sn}-\mathrm{M}$ (M is the inactive metal) alloy during the lithiation and delithiation process can be summarized as follows:

$$
\mathrm{M}_{y} \mathrm{Sn}+4.4 \mathrm{Li}^{+}+4.4 \mathrm{e}^{-} \rightarrow y \mathrm{M}+\mathrm{Li}_{4.4} \mathrm{Sn}
$$
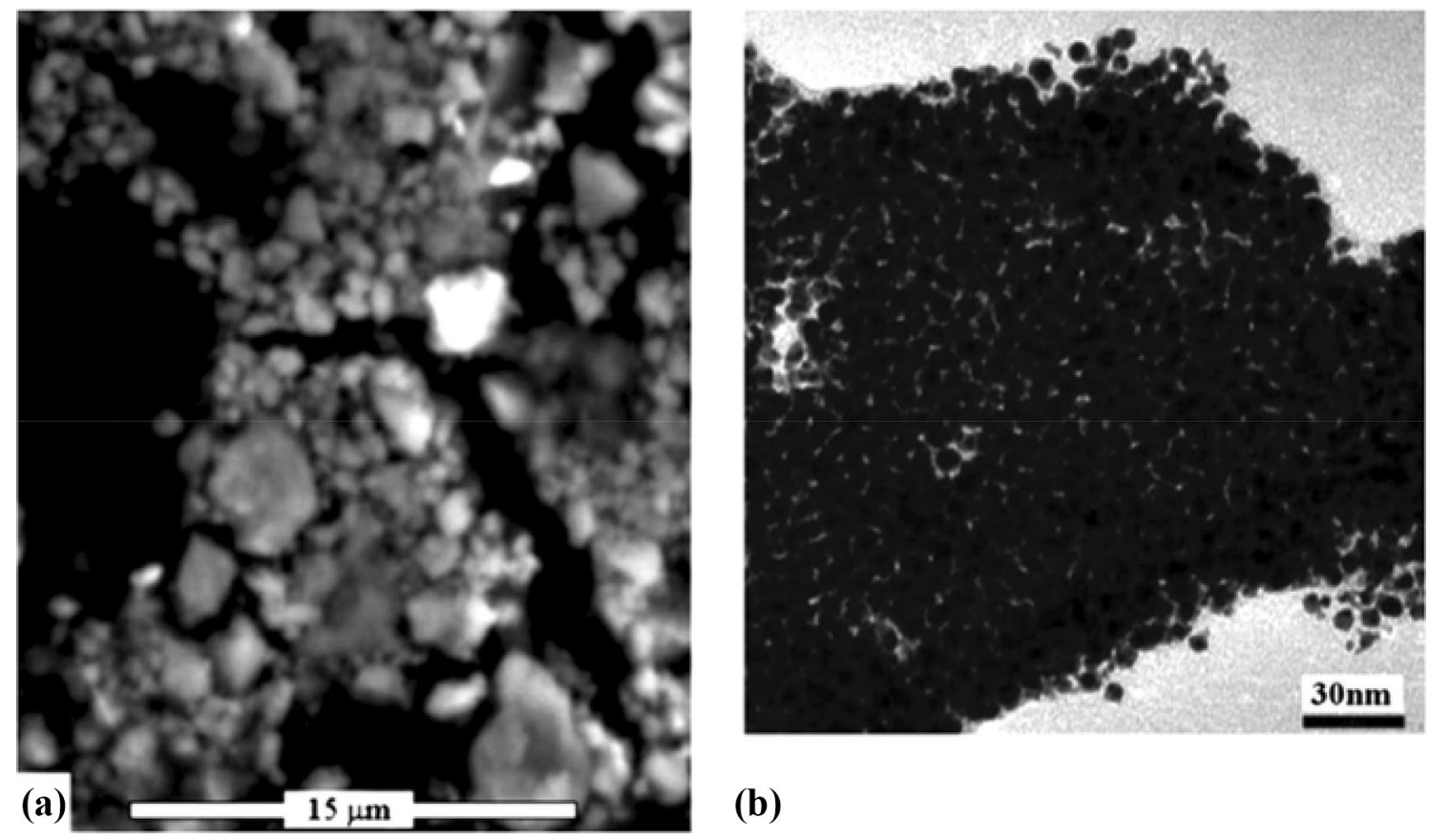

(b)

Fig. 2 SEM (a) and TEM (b) images of the amorphous tin-cobalt anode. Reproduced with permission from Ref. [25]. Copyright 2007, IOP Publishing Ltd. 
$y \mathrm{M}+\mathrm{Li}_{4.4} \mathrm{Sn} \rightarrow \mathrm{M}_{y} \mathrm{Sn}+\mathrm{M}+\mathrm{Sn}+4.4 \mathrm{Li}^{+}+4.4 \mathrm{e}^{-}$

For $\mathrm{Sn}-\mathrm{Co}, \mathrm{Sn}-\mathrm{Fe}, \mathrm{Sn}-\mathrm{Ni}$ and $\mathrm{Sn}-\mathrm{Cu}$ systems, the practical volumetric capacities of some common intermetallic compounds, shown in Table 1, are in the following order: $\mathrm{Sn}_{5} \mathrm{Fe}\left(2517 \mathrm{Ah} \mathrm{L}^{-1}\right)>\mathrm{Sn}_{2} \mathrm{Co}\left(2323 \mathrm{Ah} \mathrm{L}^{-1}\right), \mathrm{Sn}_{2} \mathrm{Fe}(2324$ $\left.\mathrm{Ah} \mathrm{L} \mathrm{L}^{-1}\right)>\mathrm{Sn}_{4} \mathrm{Ni}_{3}\left(2231 \mathrm{Ah} \mathrm{L}^{-1}\right)>\mathrm{Sn}_{5} \mathrm{Cu}_{6}\left(2056 \mathrm{Ah} \mathrm{L}^{-1}\right)$. Among them, $\mathrm{Fe}$ is non-toxic (environmentally friendly) and the least expensive (abundant), so is the obvious choice. Mao et al. [27] prepared intermetallic phases and mixtures in the Sn-Fe-C Gibbs' triangle by mechanical alloying methods or by direct melting of elemental powders. The experimental capacity for $\mathrm{Sn}_{2} \mathrm{Fe}$ was $800 \mathrm{mAh} \mathrm{g}^{-1}$. During the first charge of such cells, about $650 \mathrm{mAh} \mathrm{g}^{-1}$ of Li can be extracted up to $1.5 \mathrm{~V}$. $\mathrm{Sn}_{2} \mathrm{Fe}$ reacts in $\mathrm{Li} / \mathrm{Sn}_{2} \mathrm{Fe}$ cells to form lithium-tin alloys and very small metallic iron grains [28]. Nwokeke et al. [29] detected superparamagnetic iron (and/or tin-doped iron) nanoparticles during discharge by both electron paramagnetic resonance (EPR) and Mössbauer spectroscopy. Magnetic measurement by Dong et al. [30] showed that the particle size of $\mathrm{Fe}$ was about $3 \mathrm{~nm}$. Some Fe particles of a larger size $(5-10 \mathrm{~nm})$ could remain after the first charge. Unreacted Fe accumulation continues upon the second delithiation process, approaching those of metallic Fe. Such coarsening contributed to the capacity loss upon cycling $[28,30]$.

Similar to $\mathrm{FeSn}_{2}, \mathrm{CoSn}_{2}$ alloy could deliver an initial discharge capacity of $602 \mathrm{mAh} \mathrm{g}^{-1}$ with Coulombic efficiency of $85 \%$ [31]. The high capacity in $\mathrm{CoSn}_{2}$ and $\mathrm{FeSn}_{2}$ might be explained by the crystal structure. The open channels located within $\mathrm{CoSn}_{2}$ and $\mathrm{FeSn}_{2}$ crystal lattices, which are parallel to the [001] direction, are surrounded by adjacent $\mathrm{Sn}$ atoms, promoting the penetration and alloying of $\mathrm{Li}^{+}$with the $\mathrm{Sn}$ host [31-33]. For other $\mathrm{Sn}-\mathrm{Fe}$ or $\mathrm{Sn}-\mathrm{Co}$ alloy, such as $\mathrm{Fe}_{5} \mathrm{Sn}_{3}, \mathrm{Fe}_{3} \mathrm{Sn}_{2}, \mathrm{FeSn}, \mathrm{Co}_{3} \mathrm{Sn}_{2}$ and $\mathrm{CoSn}$, the channels are smaller, distorted and/or mixed with $\mathrm{Sn}$ atoms and transition metal atoms, which limited $\mathrm{Li}^{+}$transport. Wang et al. [34]

Table 1 Lithiated density, gravimetric and volumetric capacity of $\mathrm{Sn}, \mathrm{Sn}_{5} \mathrm{Fe}, \mathrm{Sn}_{2} \mathrm{Fe}, \mathrm{Sn}_{2} \mathrm{Co}, \mathrm{Ni}_{3} \mathrm{Sn}_{4}$ and $\mathrm{Cu}_{6} \mathrm{Sn}_{5}$ for the formation of $\mathrm{Li}_{4.4} \mathrm{Sn}+\mathrm{M}$ compared with $\mathrm{Li}$ metal and graphite

\begin{tabular}{lllll}
\hline Alloy & $\begin{array}{l}\text { Lithiated } \\
\text { density }\end{array}$ & $\begin{array}{l}\text { Gravimetric } \\
\text { capacity } \\
\left(\mathrm{mAh} \mathrm{g}^{-1}\right)\end{array}$ & $\begin{array}{l}\text { Volumetric } \\
\text { capacity }(\mathrm{Ah} \\
\left.\mathrm{L}^{-1}\right)\end{array}$ & $\begin{array}{l}\text { Volume } \\
\text { expansion } \\
(\%)\end{array}$ \\
\hline $\mathrm{Li}$ & 0.534 & 3860 & 2062 & Infinite \\
Graphite & 2.16 & 372 & 804 & $10 \%$ \\
$\mathrm{Sn}$ & 2.58 & 993 & 2562 & $258 \%$ \\
$\mathrm{Sn}_{5} \mathrm{Fe}$ & 2.71 & 929 & 2517 & $242 \%$ \\
$\mathrm{Sn}_{2} \mathrm{Fe}$ & 2.89 & 804 & 2324 & $250 \%$ \\
$\mathrm{Sn}_{2} \mathrm{Co}$ & 2.92 & 796 & 2323 & $265 \%$ \\
$\mathrm{Sn}_{4} \mathrm{Ni}_{3}$ & 3.08 & 724 & 2231 & $234 \%$ \\
$\mathrm{Sn}_{5} \mathrm{Cu}$ & 3.40 & 604 & 2056 & $174 \%$ \\
\hline
\end{tabular}

synthesized monodisperse nanospheres of the intermetallic $\mathrm{FeSn}_{5}$ phase via a nanocrystal conversion protocol using pre-formed Sn nanoparticles as templates and resolved the new phase structure, shown in Fig. $3 \mathrm{a}$. FeSn ${ }_{5}$ belongs to the tetragonal phase in the $P 4 / m c c$ space group, along with the defect structure $\mathrm{Fe}_{0.74} \mathrm{Sn}_{5}$. The lattice parameters of $\mathrm{Fe}_{0.74} \mathrm{Sn}_{5}$ were refined as $a=b=6.91369 \AA, c=5.88967 \AA$. It has a lot of similarities with that of $\mathrm{FeSn}_{2}$ (Fig. 3a, b). It has proved that $\mathrm{FeSn}_{5}$ is one intermediate phase between $\mathrm{Sn}$ and $\mathrm{FeSn}_{2}$ [34-36]. $\mathrm{Fe}_{0.74} \mathrm{Sn}_{5}$ has a high capacity of $750 \mathrm{mAh}$ $\mathrm{g}^{-1}$ (Fig. 3c), but a poor cycle life. Xin et al. synthesized $\mathrm{MSn}_{5}(\mathrm{M}=\mathrm{Fe}, \mathrm{Co}$ and $\mathrm{FeCo})$ nanoparticles with the same crystal structure, identical particle surface morphology and a similar particle size distribution $(30-50 \mathrm{~nm})$ (Fig. 3d-1), which are ideal for a comparison of the electrochemical performance, reaction mechanisms, thermodynamics and kinetics. $\mathrm{FeSn}_{5}, \mathrm{Fe}_{0.5} \mathrm{Co}_{0.5} \mathrm{Sn}_{5}$ and $\mathrm{CoSn}_{5}$ phases belong to tetragonal structure in the $P 4 / m c c$ space group. They all had a core-shell structure consisting of a 30-nm singlecrystalline intermetallic core and a $\sim$-nm amorphous oxide shell. During the charge/discharge process, some cracking of the $\mathrm{FeSn}_{5}$ nanoparticles could be clearly observed after the first cycle, while $\mathrm{Fe}_{0.5} \mathrm{Co}_{0.5} \mathrm{Sn}_{5}$ and $\mathrm{CoSn}_{5}$ almost kept their original morphology. After 100 cycles, only the Fe signal could be detected in the region of TEM image, indicating the separation of Fe from Sn and aggregation of Sn particles may result in a quick capacity decline of $\mathrm{FeSn}_{5}$ [37].

This issue of capacity decay needs to be addressed. In general, the method of ball milling is favored by industry. Dahn reported earlier on the $\mathrm{Sn}-\mathrm{Fe}$ system including $\mathrm{Sn}_{2} \mathrm{Fe}-\mathrm{C}$ and $\mathrm{Sn}_{2} \mathrm{Fe} / \mathrm{SnFe}_{3} \mathrm{C}$ active/inactive composites [27, 38]. A microscopic mixture of $25 \% \mathrm{Sn}_{2} \mathrm{Fe}$ (active) and $75 \% \mathrm{SnFe}_{3} \mathrm{C}$ (inactive) shows $200 \mathrm{mAh} \mathrm{g}^{-1}$ with good capacity retention for 50 cycles. Using the mechanochemical method, which is low cost, facile and easily scaled up, a $\mathrm{Sn}-\mathrm{Fe}-\mathrm{C}$ composite was prepared [10]. $\mathrm{Ti}, \mathrm{Al}$ and $\mathrm{Mg}$ were used as the reducing agents with different grinding media. The result showed that these nanosized $\mathrm{Sn}-\mathrm{Fe}-\mathrm{C}$ based alloys produced by titanium reduction have much better capacity retention. Similar to Ti in Sony's amorphous $\mathrm{SnCoC}$ anode, the role of titanium was probably to stabilize the compound. For grinding media (soft iron, hard iron and zirconia), the material of Ti-reducing agents with soft iron balls displayed higher capacity than graphitic carbon even after 280 cycles. Figure $4 \mathrm{a}-\mathrm{f}$ shows the comparison between nanosized $\mathrm{Sn}-\mathrm{Fe}-\mathrm{C}$ alloy with $\mathrm{Ti}$ as a reducing agent prepared by using a soft steel grinding medium and Sony's SnCoC material. The discharge and charge rate capabilities of $\mathrm{Sn}-\mathrm{Fe}-\mathrm{C}$ composites were superior to that of commercial $\mathrm{SnCoC}$ anodes without the need of expensive cobalt.

Further, Dong et al. [39] optimized the total grinding time, the graphite content, the carbon type and the $\mathrm{Ti}$ 
(a)

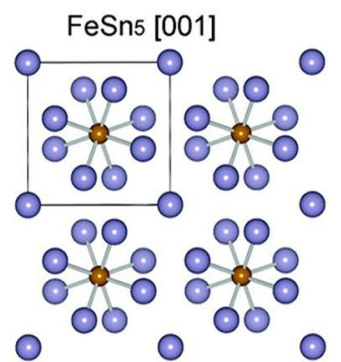

(b)

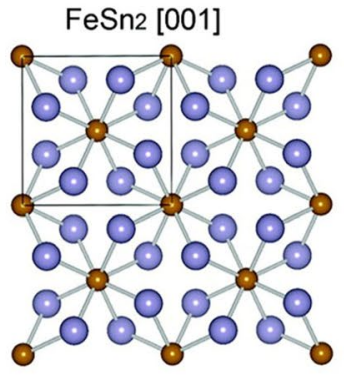

(c)

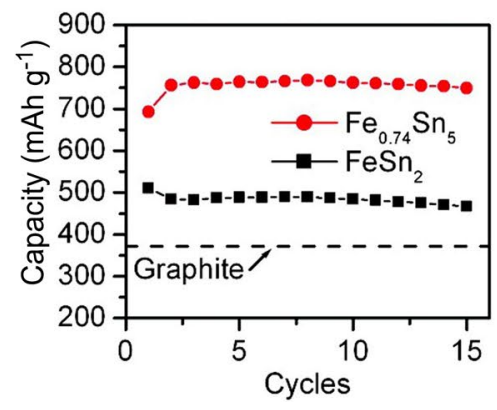

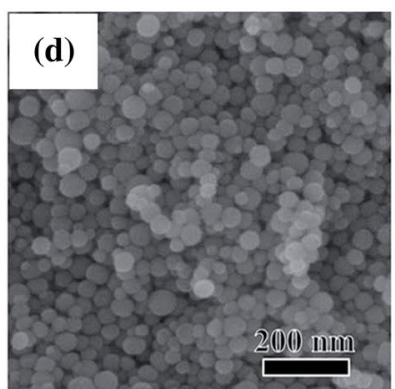
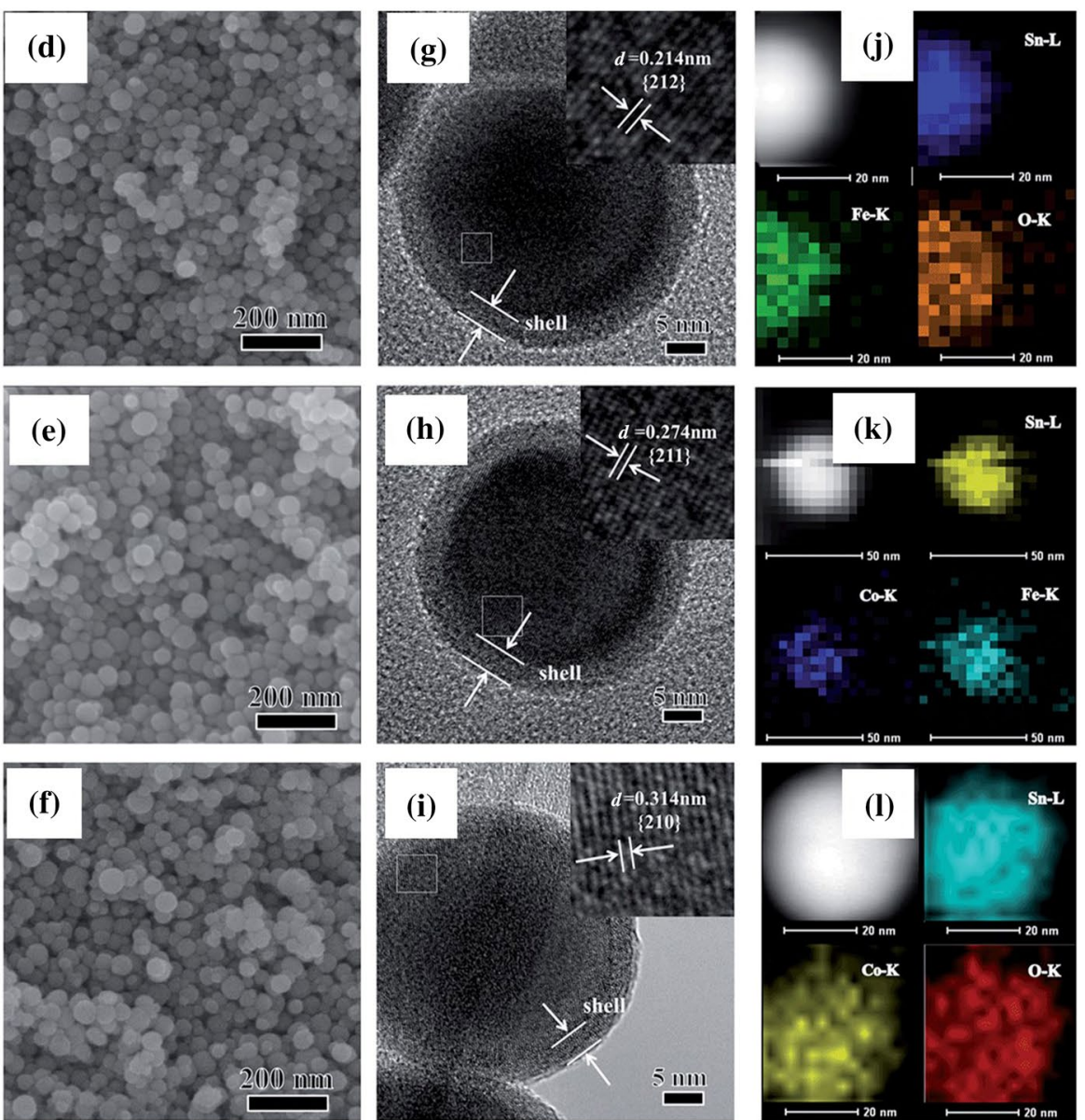

Fig. 3 a, b $\mathrm{FeSn}_{5}$ and $\mathrm{FeSn}_{2}$ crystal structures from the [001] view direction; $\mathbf{c}$ reversible capacities of $\mathrm{FeSn}_{5}$ and $\mathrm{FeSn}_{2}$ nanospheres as anodes in Li-ion batteries. Reproduced with permission from Ref. [34]. Copyright 2011, American Chemical Society. d-f SEM; g-i

content. They showed that the optimum mechanochemical synthetic conditions are mixing $\mathrm{SnO}, \mathrm{Ti}$ and graphite with a molar ratio of 1:0.25:10 and total grinding time of $8 \mathrm{~h}$ by using hard balls. Such optimized $\mathrm{Sn}-\mathrm{Fe}-\mathrm{C}$ composite could deliver 2.4 $\mathrm{Ah} \mathrm{mL}^{-1}$ for the first charge and maintain $60 \%$ of its original capacity for 170 cycles at a $\mathrm{C} / 10$ rate. The $\mathrm{Sn}-\mathrm{Fe}-\mathrm{C}$ composite also displayed excellent rate capability with $1.6 \mathrm{Ah} \mathrm{mL}^{-1}$ over 140 cycles at a $1 \mathrm{C}$ rate, corresponding to about double that of graphite displayed in Fig. 4g, h. Interestingly, the capacity after the first cycle was larger than that of the formation of $\mathrm{Li}_{4.4} \mathrm{Sn}$ and $\mathrm{LiC}_{6}$, and some highly saturated $\mathrm{LiC}_{2}$ could be invoked.

\subsection{The Design of Sn-Fe-(C) and Sn-C Nanostructure Materials}

Design and exploration of nanostructure materials are effective methods to improve the electrochemical performance of Sn-based alloy, which could reduce the absolute
HRTEM; and j-l STEM-EDS elemental mapping images of $\mathrm{FeSn}_{5}$, $\mathrm{Fe}_{0.5} \mathrm{Co}_{0.5} \mathrm{Sn}_{5}$ and $\mathrm{CoSn}_{5}$ nanospheres. Reproduced with permission from Ref. [37]. Copyright 2015, The Royal Society of Chemistry

volume change, shorten ion and electron transport lengths, and benefit permeation of electrolytes, thus enhancing the reaction kinetics during the lithium insertion/extraction process. Dispersing $\mathrm{Sn}-(\mathrm{Fe})$ alloy nanoparticles in a carbon matrix with some void space can alleviate the volume expansion, which could largely improve the electrochemically cycling and rate performance, such as $\mathrm{Fe}_{0.74} \mathrm{Sn}_{5} @$ reduced graphene oxide nanocomposites [40]. Among them, pyrolysis of carbon matrix precursors with $\mathrm{Sn}-(\mathrm{Fe})$ sources toward preparation of nanostructured materials has received researchers' much attention. Table 2 summarizes electrochemical performance including the voltage range, the mass loading, the ratio among active materials, the binder and carbon, initial Coulombic efficiency and cycling stability of some typical $\mathrm{Sn}-(\mathrm{Fe})-\mathrm{C}$ alloys with different structures [41-54]. Although the introduction of a carbon source (graphene, amorphous porous carbon, ordered mesoporous carbon and carbon nanotubes/ nanofibers) and void space can bring good electrochemical 
Fig. 4 Lithium removal and insertion rate capability of $\mathrm{Sn}-$ $\mathrm{Fe}-\mathrm{C}$ alloy in the voltage range of 0.01-1.2 V (a, b), 0.01-1.5 V $(\mathbf{c}, \mathbf{d})$ and the corresponding capacity retention $(\mathbf{e}, \mathbf{f})$ with Sony's amorphous SnCo anode. Reproduced with permission from Ref. [10]. Copyright 2011, IOP Publishing Ltd. g, h Volumetric capacity of optimized $\mathrm{Sn}-\mathrm{Fe}-\mathrm{C}$ composites cycled under $\mathrm{C} / 10$ and $1 \mathrm{C}$. Reproduced with permission from Ref. [39]. Copyright 2016, Wiley
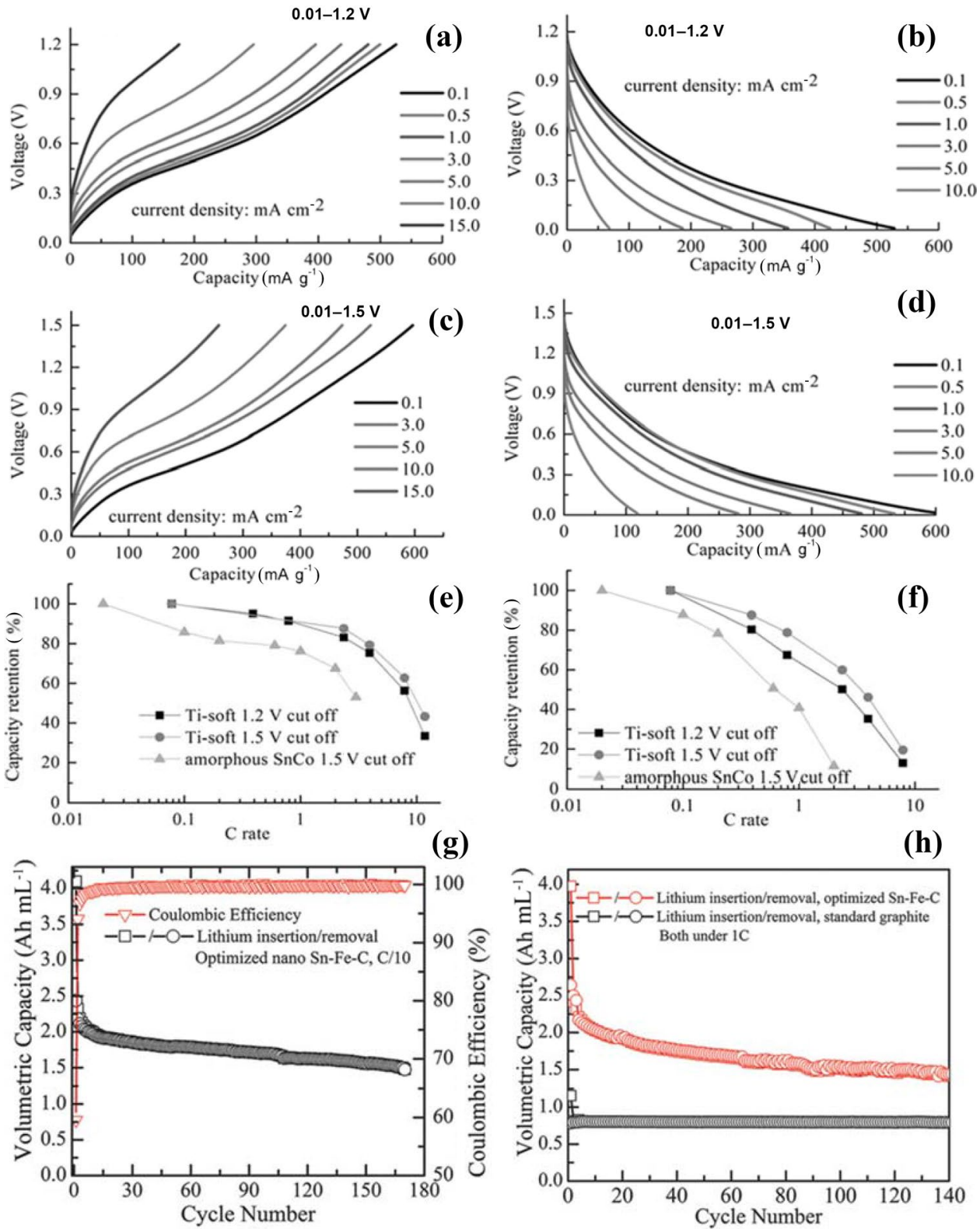

(h)

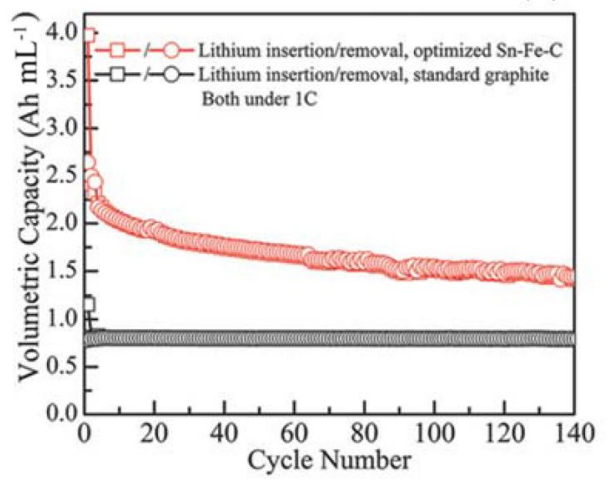

performance, more than 1000 cycles with high gravimetric capacity, the volumetric energy density may be greatly reduced. Moreover, the structure of porous, or void, or large surface areas will need a large amount of electrolytes.

Xin et al. [36] designed a series of nanosized $\mathrm{Sn}_{y} \mathrm{Fe}$ alloys, which was derived from the chemical transformation of pre-formed Sn nanoparticles as templates. Their results show that $\mathrm{Sn}_{5} \mathrm{Fe}$ alloy is the main phase at lower temperature and that $\mathrm{Sn}_{2} \mathrm{Fe}$ always exists in higher temperature, even with a high $\mathrm{Sn}$ ratio. The stability of $\mathrm{Sn}_{5} \mathrm{Fe}$ alloy decreases with increasing temperature. Both the composition and the morphology of $\mathrm{Sn}-\mathrm{Fe}$ alloy can be controlled by adjusting temperature and reagent molar ratios. Figure $5 a-h$ shows the primary particle sizes of the four $\mathrm{Sn}-\mathrm{Fe}$ alloys are tens of nanometers, and the morphology changes with the increasing Fe reactant content from spherical to cubic and to ultrasmall/irregular particles. The composition is $\mathrm{Sn}_{5} \mathrm{Fe}$ for $\mathrm{Sn}-\mathrm{Fe}-1$ and $\mathrm{Sn}-\mathrm{Fe}-2, \mathrm{Sn}_{5} \mathrm{Fe} @ \mathrm{Sn}_{2} \mathrm{Fe}$ for $\mathrm{Sn}-\mathrm{Fe}-3$ and $\mathrm{Sn}_{2} \mathrm{Fe}$ for Sn-Fe-4, shown in Fig. 5i-p. Furthermore, the Sn-Fe-3 sample with $\mathrm{Sn}_{5} \mathrm{Fe} @ \mathrm{Sn}_{2} \mathrm{Fe}$ displays core-shell structure, where the shell is $\mathrm{Sn}_{2} \mathrm{Fe}$ with a core of $\mathrm{Sn}_{5} \mathrm{Fe}$. The formation mechanism was as follows: $\mathrm{Sn}_{5} \mathrm{Fe}$ was first formed by using $\mathrm{Sn}$ as a template when the Fe reactant content was low; gradually, $\mathrm{Sn}_{5} \mathrm{Fe}$ was transferred to $\mathrm{Sn}_{2} \mathrm{Fe}$ from the surface of the particles as more and more $\mathrm{Fe}$ reactants were added; finally, $\mathrm{Sn}_{2} \mathrm{Fe}$ will spread through the whole particles.

Cycling and rate performance of a series of $\mathrm{Sn}-\mathrm{Fe}$ alloys was tested in the voltage range of $0.01-1.5 \mathrm{~V}$, displayed in Fig. 5q-r. Sn-Fe-1 material with Fe defects had $\sim 1.43 \mathrm{Ah}$ $\mathrm{mL}^{-1}$ for 25 cycles, and then, the capacity quickly decayed 
Table 2 Summary of structures, voltage ranges, mass loading, ratios among active materials, binders and carbon, initial Coulombic efficiency, cycling stability of some $\mathrm{Sn}-(\mathrm{Fe})-\mathrm{C}$ alloys as anodes in lithium-ion batteries

\begin{tabular}{|c|c|c|c|c|c|c|c|c|c|}
\hline \multirow{2}{*}{$\begin{array}{l}\text { Sn-(Fe)-C } \\
\text { alloy with } \\
\text { different } \\
\text { structures }\end{array}$} & \multirow{2}{*}{$\begin{array}{l}\text { Voltage range } \\
\text { (V) }\end{array}$} & \multirow{2}{*}{$\begin{array}{l}\text { Mass } \\
\text { loading } \\
\left(\mathrm{mg} \mathrm{cm}^{-2}\right)\end{array}$} & \multirow{2}{*}{$\begin{array}{l}\text { Active mate- } \\
\text { rial/binder/ } \\
\text { carbon }\end{array}$} & \multirow{2}{*}{$\begin{array}{l}\text { Initial } \\
\text { Coulombic } \\
\text { efficiency }(\%)\end{array}$} & \multicolumn{4}{|c|}{ Cycling stability } & \multirow[t]{2}{*}{ Reference } \\
\hline & & & & & $\begin{array}{l}\text { Current } \\
\text { density }\end{array}$ & $\begin{array}{l}\text { Cycling } \\
\text { number }\end{array}$ & $\begin{array}{l}\text { Capacity } \\
(\mathrm{mAh} \\
\left.\mathrm{g}^{-1}\right)\end{array}$ & $\begin{array}{l}\text { Capacity } \\
\text { retention } \\
(\%)\end{array}$ & \\
\hline $\begin{array}{l}\text { Nanoporous } \\
\text { Sn-Fe@C }\end{array}$ & $0.01-2.0$ & - & $70: 15: 15$ & - & $0.1 \mathrm{~A} \mathrm{~g}^{-1}$ & 100 & 441 & 57 & {$[41]$} \\
\hline $\begin{array}{l}\text { Ultrafine } \mathrm{Sn}- \\
\text { Fe alloys in } \\
\text { hierarchi- } \\
\text { cal carbon } \\
\text { frameworks }\end{array}$ & $0.01-2.0$ & - & $80: 10: 10$ & 55 & $0.1 \mathrm{~A} \mathrm{~g}^{-1}$ & 500 & 516 & 62.5 & {$[42]$} \\
\hline $\begin{array}{l}\text { Ultrafine Sn } \\
\text { in hierarchi- } \\
\text { cally porous } \\
\mathrm{N} \text {-doped } \\
\text { carbon }\end{array}$ & $0.05-3.0$ & $0.1-0.15$ & $80: 10: 10$ & 78.5 & $0.1 \mathrm{~A} \mathrm{~g}^{-1}$ & 300 & 788 & 92.4 & [43] \\
\hline $\begin{array}{l}\text { Double- } \\
\text { shelled hol- } \\
\text { low carbon } \\
\text { spheres } \\
\text { confining } \\
\text { tin }\end{array}$ & $0.01-3.0$ & $0.9-1.2$ & $80: 10: 10$ & 62 & $0.1 \mathrm{~A} \mathrm{~g}^{-1}$ & 130 & 1100 & 77.8 & [44] \\
\hline $\begin{array}{l}\text { Graphene- } \\
\text { confined Sn } \\
\text { nanosheets }\end{array}$ & $0.05-2.0$ & - & $80: 10: 10$ & 66.5 & $50 \mathrm{~mA} \mathrm{~g}^{-1}$ & 60 & 590 & 64 & [45] \\
\hline $\begin{array}{l}\text { Graphene } \\
\text { networks } \\
\text { anchored } \\
\text { with Sn@ } \\
\text { graphene }\end{array}$ & $0.005-3.0$ & - & $80: 10: 10$ & 69 & $0.2 \mathrm{~A} \mathrm{~g}^{-1}$ & 100 & 1089 & 87.5 & [46] \\
\hline $\begin{array}{l}\text { Uniform } \\
\text { nano-Sn/C } \\
\text { composite }\end{array}$ & $0-3.0$ & 1.0 & $70: 15: 15$ & 69 & $0.25 \mathrm{C}$ & 130 & 710 & 100 & [47] \\
\hline $\begin{array}{l}\text { Ultrasmall } \\
\text { Sn nano- } \\
\text { particles } \\
\text { embedded } \\
\text { in nitrogen- } \\
\text { doped } \\
\text { porous } \\
\text { carbon }\end{array}$ & $0.01-2.0$ & - & $80: 10: 10$ & 75 & $0.2 \mathrm{~A} \mathrm{~g}^{-1}$ & 200 & 722 & 95.4 & [48] \\
\hline $\begin{array}{l}\text { Encapsulated } \\
\text { Sn nano- } \\
\text { particles in } \\
\text { amorphous } \\
\text { carbon } \\
\text { nanotubes }\end{array}$ & $0.01-2.0$ & 1.5 & $70: 10: 20$ & 63.2 & $0.2 \mathrm{~A} \mathrm{~g}^{-1}$ & 100 & 749 & 71 & [49] \\
\hline $\begin{array}{l}\text { Sn-based } \\
\text { nanoparti- } \\
\text { cles encap- } \\
\text { sulated in a } \\
\text { porous 3D } \\
\text { graphene } \\
\text { network }\end{array}$ & $0.005-3.0$ & 1.5 & $80: 10: 10$ & 63 & $2 \mathrm{Ag}^{-1}$ & 1500 & 566 & 80 & {$[50]$} \\
\hline
\end{tabular}


Table 2 (continued)

\begin{tabular}{|c|c|c|c|c|c|c|c|c|c|}
\hline \multirow{2}{*}{$\begin{array}{l}\text { Sn-(Fe)-C } \\
\text { alloy with } \\
\text { different } \\
\text { structures }\end{array}$} & \multirow{2}{*}{$\begin{array}{l}\text { Voltage range } \\
\text { (V) }\end{array}$} & \multirow{2}{*}{$\begin{array}{l}\text { Mass } \\
\text { loading } \\
\left(\mathrm{mg} \mathrm{cm}^{-2}\right)\end{array}$} & \multirow{2}{*}{$\begin{array}{l}\text { Active mate- } \\
\text { rial/binder/ } \\
\text { carbon }\end{array}$} & \multirow{2}{*}{$\begin{array}{l}\text { Initial } \\
\text { Coulombic } \\
\text { efficiency (\%) }\end{array}$} & \multicolumn{4}{|c|}{ Cycling stability } & \multirow[t]{2}{*}{ Reference } \\
\hline & & & & & $\begin{array}{l}\text { Current } \\
\text { density }\end{array}$ & $\begin{array}{l}\text { Cycling } \\
\text { number }\end{array}$ & $\begin{array}{l}\text { Capacity } \\
(\mathrm{mAh} \\
\left.\mathrm{g}^{-1}\right)\end{array}$ & $\begin{array}{l}\text { Capacity } \\
\text { retention } \\
(\%)\end{array}$ & \\
\hline $\begin{array}{l}\text { Inserting Sn } \\
\text { nanopar- } \\
\text { ticles into } \\
\text { the pores of } \\
\mathrm{TiO}_{2-y}-\mathrm{C} \\
\text { nanofibers }\end{array}$ & $0-3.0$ & - & $80: 10: 10$ & 67 & $0.1 \mathrm{~A} \mathrm{~g}^{-1}$ & 200 & 957 & 91.6 & {$[51]$} \\
\hline $\begin{array}{l}\text { Tailored } \\
\text { yolk-shell } \\
\text { Sn@C } \\
\text { nanoboxes }\end{array}$ & $0.005-3.0$ & 1.0 & $80: 10: 10$ & 61 & $0.2 \mathrm{~A} \mathrm{~g}^{-1}$ & 500 & 810 & 90 & {$[52]$} \\
\hline $\begin{array}{l}\text { Ultrasmall } \\
\text { Sn nano- } \\
\text { particles } \\
\text { embedded } \\
\text { in spherical } \\
\text { hollow } \\
\text { carbon }\end{array}$ & $0.05-2.0$ & $1.5-2.0$ & $80: 10: 10$ & 71.9 & $4.0 \mathrm{~A} \mathrm{~g}^{-1}$ & 6000 & 423 & 92.1 & {$[53]$} \\
\hline $\begin{array}{l}\text { Ultrasmall Sn } \\
\text { nanodots } \\
\text { embed- } \\
\text { ded inside } \\
\text { N-doped } \\
\text { carbon } \\
\text { microcages }\end{array}$ & $0.005-2.0$ & 0.8 & $80: 10: 10$ & 55 & $1 \mathrm{Ag}^{-1}$ & 1600 & 437 & 74.2 & {$[54]$} \\
\hline
\end{tabular}

to $\sim 0.64 \mathrm{Ah} \mathrm{mL}^{-1}$ after 100 cycles. Sn-Fe-2 material with richer Fe delivered a capacity of $\sim 1.48 \mathrm{Ah} \mathrm{mL}^{-1}$ for 25 cycles and still kept $1.31 \mathrm{Ah} \mathrm{mL}^{-1}$ after 100 cycles. The $\mathrm{Sn}-\mathrm{Fe}-3$ sample with core-shell structure shows superior capacity retention, in which the capacity maintained 1.55 $\mathrm{Ah} \mathrm{mL}^{-1}$ after 200 cycles at the $\mathrm{C} / 2$ rate, corresponding to nearly $100 \%$ of the initial capacity and $\sim 90.2 \%$ of the highest charging capacity. The average capacity loss of $\mathrm{Sn}-\mathrm{Fe}-3$ anodes was only $0.049 \%$ per cycle according to $90.2 \%$ capacity retention, and Coulombic efficiency exceeded $99.5 \%$ for most of the cycles. The capacity of $\mathrm{Sn}-\mathrm{Fe}-4$ electrodes with the highest initial capacity gradually dropped. Therefore, the calculated volumetric capacity of the core-shell anode, $\mathrm{Sn}-\mathrm{Fe}-3$, is close to twice that of carbon $\left(0.8 \mathrm{Ah} \mathrm{mL}^{-1}\right)$ after 200 cycles. Further, the core-shell $\mathrm{Sn}-\mathrm{Fe}-3$ electrode could deliver $94.8 \%, 84.3 \%$, $72.1 \%$ and $58.2 \%$ of the $0.1 \mathrm{C}$ capacity at $0.2 \mathrm{C}, 0.5 \mathrm{C}, 1 \mathrm{C}$ and $2 \mathrm{C}$ and show the best maintenance of capacity after 90 cycles among the four samples.

\section{Toward Commercialization}

\subsection{Key Requirements of Anode in Commercialization}

To satisfy the high energy requirement of commercial anode, several parameters are really important.

\subsubsection{Volumetric Capacity}

For all alloy-based anodes, the volumetric and gravimetric capacities of the active elements are higher than that of graphite. Further, volumetric capacities are more important in practical cells, no matter in portable communication electronics, battery electric vehicles, plug-in hybrid electric vehicles or hybrid electric vehicles. For Sn-based materials, the theoretical volumetric capacity $\left(2562 \mathrm{Ah} \mathrm{L}^{-1}\right)$ after lithiation is essentially the same as that of pure lithium (2062 Ah $\mathrm{L}^{-1}$ ) and is 2.5 times larger than that of graphite. Sn-based materials are good candidates to replace graphitic carbon as the anode for the next-generation lithium-ion batteries. However, much of the research has only focused on gravimetric capacities or calculated with respect to alloy volume before lithiation. The true volumetric capacity must be calculated 
Fig. 5 (a-d) SEM images, (e-h) TEM images, (i-l) SAED images and (m-p) HRTEM images zooming in local areas in corresponding TEM images of the four materials: $\mathrm{Sn}-\mathrm{Fe}-1$, $\mathrm{Sn}-\mathrm{Fe}-2, \mathrm{Sn}-\mathrm{Fe}-3$ and $\mathrm{Sn}-\mathrm{Fe}-4$; q-r cycling and rate performance of Sn-Fe-1, Sn-Fe-2, $\mathrm{Sn}-\mathrm{Fe}-3$ and $\mathrm{Sn}-\mathrm{Fe}-4$ samples. Reproduced with permission from Ref. [36]. Copyright 2019, American Chemical Society
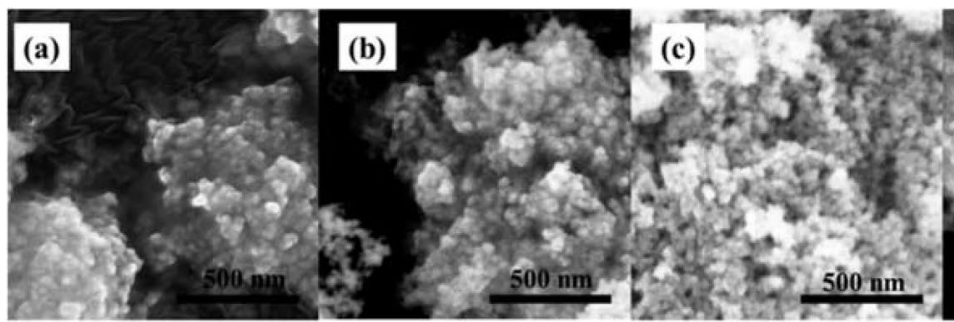

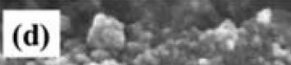
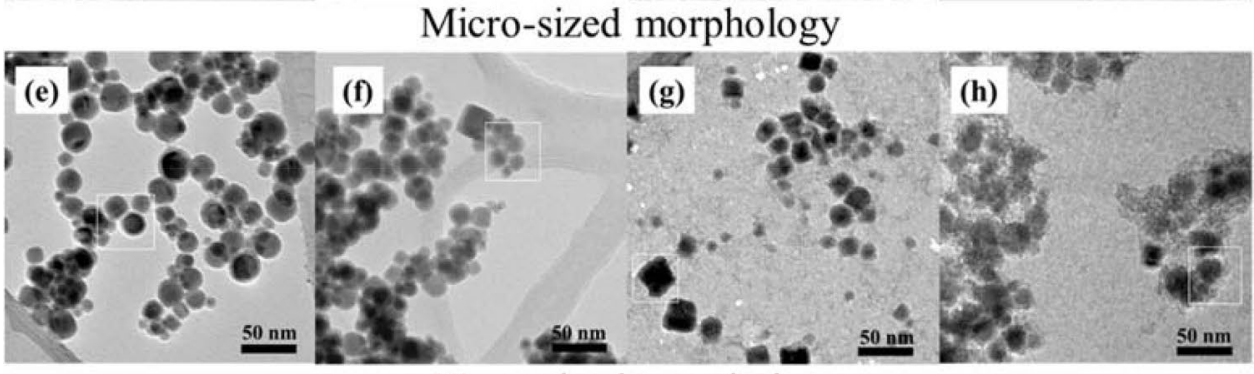

Nano-sized morphology

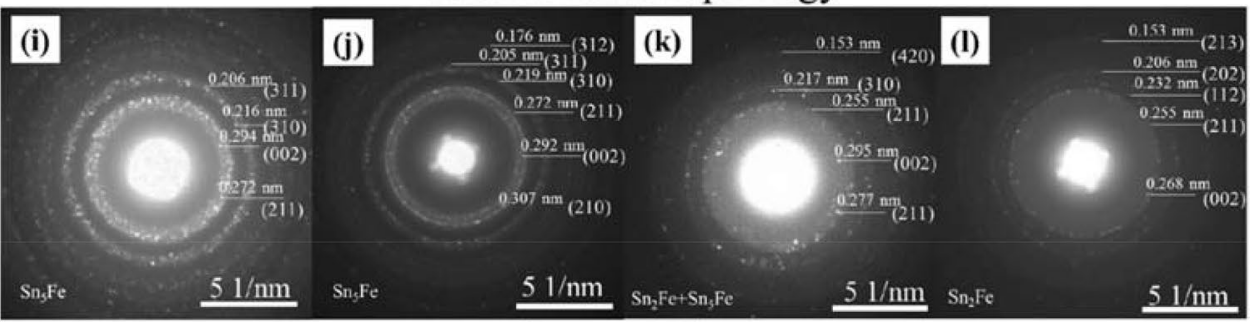

Composition

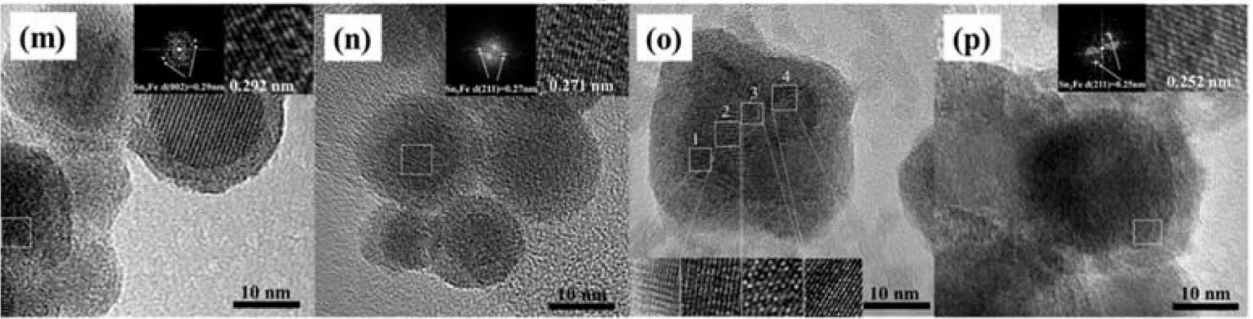

Capacity retention
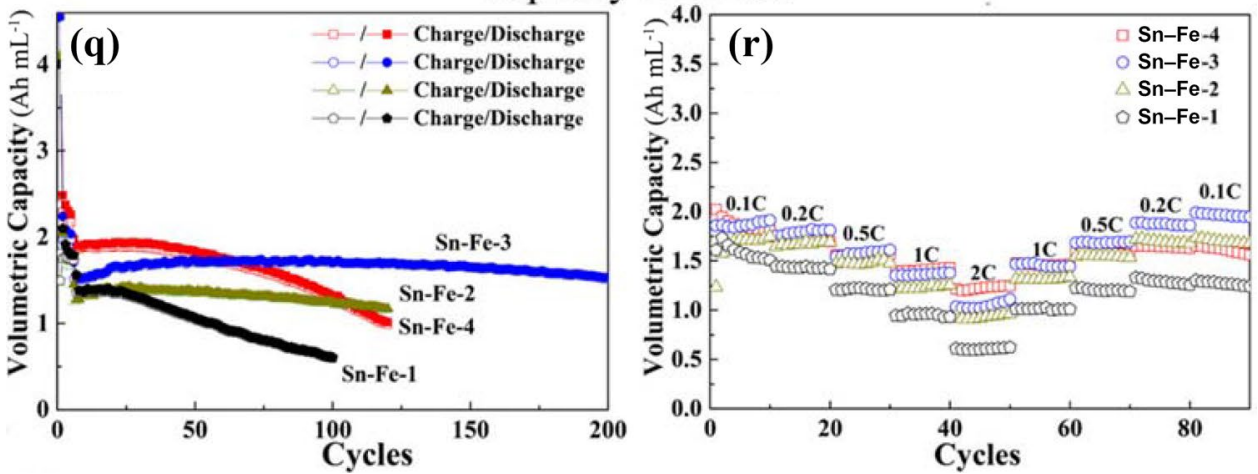

in the fully charged state, as for these tin-based materials, the volume of the lithiated anode is much larger (approaching $300 \%$ larger) than that of $\mathrm{Sn}$ or $\mathrm{Sn}_{y} \mathrm{M}$. In contrast, the volume of the cathode changes by less than $10 \%$. In addition, the introduction of a large porous/void structure or an inactive matrix will greatly reduce the volumetric energy density; so even if the cycling performance is improved, it is not a positive approach. Using a mechanochemical method, we prepared a $\mathrm{Sn}-\mathrm{Fe}-\mathrm{C}$ alloy [39], which has superior discharge and charge rates than Sony's $\mathrm{SnCoC}$ anode. It also displayed a volumetric capacity of $1600 \mathrm{Ah} \mathrm{L}^{-1}$ over 140 cycles at a $1 \mathrm{C}$ rate, corresponding to about double that of 
graphite. For nanostructured Sn-Fe alloy [36], the volumetric capacity attained $1550 \mathrm{Ah} \mathrm{L}^{-1}$ after 200 cycles at a current density of $0.5 \mathrm{C}$, corresponding to nearly $100 \%$ of the initial capacity and $\sim 90.2 \%$ of the highest charging capacity. The Coulombic efficiency exceeded $99 \%$ after the first cycles, showing that the performance is stabilized without the need of a large porous structure.

\subsubsection{Working Voltage Range}

In addition to the volumetric capacity, the working voltage range is another critical parameter for anode use. For graphite, it has an average voltage of $150 \mathrm{mV}$ versus $\mathrm{Li} / \mathrm{Li}^{+}$and a flat voltage profile, rendering a high overall full cell voltage. For the $\mathrm{Sn}$ anode, the plateau voltage is $0.77,0.69,0.448$, $0.446,0.439,0.437$ and $0.426 \mathrm{~V}$ for $\mathrm{Li}_{2} \mathrm{Sn}_{5}, \mathrm{LiSn}, \mathrm{Li}_{7} \mathrm{Sn}_{3}$, $\mathrm{Li}_{5} \mathrm{Sn}_{2}, \mathrm{Li}_{13} \mathrm{Sn}_{5}, \mathrm{Li}_{7} \mathrm{Sn}_{2}$ and $\mathrm{Li}_{22} \mathrm{Sn}_{5}$ (or $\mathrm{Li}_{17} \mathrm{Sn}_{4}$ ), respectively [55]. Although the voltage of Li-Sn alloy is a little higher than that of graphite, which will decrease the full cell voltage, it is safer than graphite as it inhibits the potential nucleation and growth of lithium dendrites. In addition, in the case of thermal runaways and fire, the energy of combustion is much less for tin- than for a carbon-based anode. The cycling stability of alloy anodes can be improved by controlling either lower or upper cutoff voltage ranges [14, 23], which controls volume expansion/contraction of particles and cracking/pulverization of electrodes. Moreover, the volumetric capacity at around $2 \mathrm{Li} / \mathrm{Sn}$ reaches more than double that of carbon, as shown in Fig. 1. However, there are a number of reports of Sn-based composites with different structures and morphology, a large range of voltage and a sloping voltage profile to get more gravimetric capacity, which will result in low working voltage in full cells. Table 2 summarizes the electrochemical performance of some $\mathrm{Sn}-(\mathrm{Fe})-\mathrm{C}$ alloys in different voltage ranges; for example, it is too broad when the voltage range was set between 0 and $3.0 \mathrm{~V}$.

\subsubsection{Cycling Stability}

The cycling life of a lithium-ion battery is the number of full charge-discharge cycles to reach $80 \%$ of the battery capacity. It is mainly affected by charge/discharge current density, voltage ranges and temperature [56]. For the half-cell, lithium metal was used as both counter and reference electrodes. Cyclable lithium is infinitely supplied from the lithium metal, and there is an excess electrolyte enough for its consumption. Tin-based materials in many reports can have long cycling with good capacity retention at high charge/discharge rates, as shown in Table 2 [43, 46-48, 51-53]. When a tin-based anode was combined with a cathode in a full cell, the lithium source and the electrolyte are limited. Any consumption of cyclable lithium and electrolytes originating from the side reactions will lead to fast cycling deterioration in a full cell.

Other parameters, such as ratios among active materials, binders, carbon and mass loading of electrode, will all affect the cycling stability and energy density of anodes.

\subsubsection{Choice of Electrolyte}

The commercial electrolytes in lithium-ion batteries are nonaqueous solutions, in which normally the lithium hexafluorophosphate $\left(\mathrm{LiPF}_{6}\right)$ salt is dissolved in different organic carbonate solvents. These include ethylene carbonate (EC), propylene carbonate (PC), diethyl carbonate (DEC), dimethyl carbonate (DMC) and/or ethyl methyl carbonate (EMC). To improve the capacity retention and Coulombic efficiency of tin-based anodes, fluoroethylene carbonate (FEC) is always added into the electrolyte. Seo et al. [57] showed that cells containing either 5\% or 10\% FEC have the best capacity retention and the lowest electrochemical impedance. Yang et al. [58] revealed that the additive amount of $2 \%$ FEC is enough to derive the benefits in the cells when the current density is C/9. In Sony's patent, they tried different combinations of the electrolytes, showing that if the solvent contained FEC, the cycle characteristics were improved and the FEC content could be in a large range from 1 to $80 \mathrm{wt} \%$ [59]. A stable FEC-derived SEI layer may be the reason for improved cycling stability, while continuous electrolyte decomposition and variation in the composition and concentration of the SEI species are observed in EC-based electrolytes in Sn-based electrodes [60].

\subsection{Challenge}

At present, carbon-based materials cannot satisfy the everincreasing energy density needs for mass deployment of EVs due to their low gravimetric/volumetric capacity ( $340 \mathrm{mAh}$ $\mathrm{g}^{-1}$ or $747 \mathrm{Ah} \mathrm{L}^{-1}$ ). Ideally, lithium metal should be used, but it faces the challenge of formation and growth of dendrites. Tin-based materials with higher volumetric capacity and lower working voltage are scientifically one of the most promising candidates to replace graphite. Until now, various Sn-based materials have been designed and explored. However, some of them cannot meet the requirement of high energy density when volumetric capacity, working voltage ranges, mass loading, binders and carbon are considered. From Sony's SnCoC to our Sn-Fe-C or SnFe alloy, the first cycle capacity loss needs to be improved.

The irreversible capacity loss in the first cycle comes from (1) electrolyte decomposition/formation of the SEI film at the electrode/electrolyte surface. SEI films are mainly composed of $\mathrm{Li}_{2} \mathrm{CO}_{3}$ and lithium alkyl carbonates $\left(\mathrm{ROCO}_{2} \mathrm{Li}\right)$ 
in tin-based materials [61-63]. On cycling, the SEI film will become thicker and thicker, contributing to both initial Coulombic efficiency and the later capacity decay. (2) Reduction of the surface oxidized layer. The surface amorphous oxide layer always exists in Sn-based materials after exposure to air. Protesescu et al. [64] demonstrated that the surface of Sn nanoparticles was covered with shell1/shell2 structure of $\mathrm{SnO} / \mathrm{SnO}_{2}$ phases, using surface-enhanced nuclear magnetic resonance, Mössbauer and X-ray absorption spectroscopy. During the lithiation process, the surface-oxidized layer was reduced to $\mathrm{Sn}$ and $\mathrm{Li}_{2} \mathrm{O}$ before $\mathrm{Sn}$ reacts with $\mathrm{Li}$ to form Li-Sn alloy. (3) Defective carbon. Defective carbon resulting from high energy milling is believed to be another major reason for the first cycle larger charge capacity. This is supported by Matsumura's results [65] that in addition to the graphitic layers storing lithium, the edge of graphitic layers and the surface of crystallites in disordered carbon formed from the ball mill process can also store lithium.

\section{Conclusion and Future Prospects}

From the beginning of 1997, tin-based materials have been considered as a possible substitute for carbon in lithium batteries due to their higher theoretical volumetric capacity than that of lithiated graphites. Encouraged by the success of Sony's 14430 battery ( $\mathrm{Sn}-\mathrm{Co}-\mathrm{C}$ anodes), various $\mathrm{Sn}-\mathrm{Fe}-\mathrm{C} /$ $\mathrm{Sn}-\mathrm{Fe} / \mathrm{Sn}-\mathrm{C}$ composites were evaluated as the anode for lithium-ion batteries. Compared with $\mathrm{Sn}-\mathrm{Co}-\mathrm{C}$ anodes, $\mathrm{Sn}-\mathrm{Fe}-\mathrm{C}$ alloy with lower price has superior discharge and charge rate capabilities. Further, the optimized Sn-Fe-C composite with a molar ratio of 1:0.25:10 and total grinding time of $8 \mathrm{~h}$ by using hard balls also displayed excellent rate capability with $1.6 \mathrm{Ah} \mathrm{mL}^{-1}$ over 140 cycles at a $1 \mathrm{C}$ rate, corresponding to about double than that of graphite. $\mathrm{Sn}_{y} \mathrm{Fe}$ nanostructured materials with core-shell structure also show superior capacity retention, in which the capacity could maintain $1.55 \mathrm{Ah} \mathrm{mL}^{-1}$ after 200 cycles at a C/2 rate, corresponding to nearly $100 \%$ of the initial capacity and $\sim 90.2 \%$ of the highest charging capacity. In addition, for $\mathrm{Sn}-\mathrm{Co}-\mathrm{C}$ alloy, the high price and toxicity of Co will minimize its use in cost-sensitive application.

However, the first cycle capacity loss resulting from the side reaction of $\mathrm{Sn}-\mathrm{Fe}-\mathrm{C}$ or $\mathrm{Sn}-\mathrm{Fe}$ alloy needs to be further reduced for commercialization. Some possible strategies include (1) thin and dense SEI films. To improve the cycling performance, fluoroethylene carbonate (FEC) as solvent was always added in the electrolyte. However, the introduction of FEC will lead to the formation of a thick SEI film. (2) The reduction of surface oxidized layers. Nanostructured materials can improve the electrochemical stability, but they will reduce the tap density, increase the consumption of SEIs and create more oxidized layers. The primary particles of the four $\mathrm{Sn}_{y} \mathrm{Fe}$ nanostructured alloys are tens of nanometers in size and are covered with a 3-5-nm amorphous oxidized layer. It is critical for nanostructured materials to design micro-sized secondary particles consisting of nanosized primary particles. Moreover, prelithiation of $\mathrm{Sn}-\mathrm{Fe}-\mathrm{C}$ or $\mathrm{Sn}-\mathrm{Fe}$ alloy anodes can directly eliminate the impact of the irreversible capacity loss. Different lithiated states can be obtained by electrochemical and chemical lithiation method.

In addition to possible use in lithium-ion batteries, tinbased materials are regarded as good candidates for sodiumion batteries (SIBs), potassium-ion batteries (KIBs), magnesium-ion batteries (MIBs) and calcium-ion batteries (CIBs). They offer higher gravimetric and volumetric capacity in these alkali (earth)-ion batteries. Meanwhile, the reaction mechanism is likely similar in all the battery systems. The development and application of tin-based materials in LIBs provide insights for these other battery systems.

Acknowledgements This work was supported by the Assistant Secretary for Energy Efficiency and Renewable Energy (Grant No. DE-EE0007765), Office of Vehicle Technologies of the U.S. Department of Energy, through the Advanced Battery Materials Research Program (Battery500 Consortium).

Open Access This article is licensed under a Creative Commons Attribution 4.0 International License, which permits use, sharing, adaptation, distribution and reproduction in any medium or format, as long as you give appropriate credit to the original author(s) and the source, provide a link to the Creative Commons licence, and indicate if changes were made. The images or other third party material in this article are included in the article's Creative Commons licence, unless indicated otherwise in a credit line to the material. If material is not included in the article's Creative Commons licence and your intended use is not permitted by statutory regulation or exceeds the permitted use, you will need to obtain permission directly from the copyright holder. To view a copy of this licence, visit http://creativecommons.org/licenses/by/4.0/.

\section{References}

1. Whittingham, M.S.: Electrical energy storage and intercalation chemistry. Science 192, 1126-1127 (1976). https://doi. org/10.1126/science.192.4244.1126

2. Kang, K.: Electrodes with high power and high capacity for rechargeable lithium batteries. Science 311, 977-980 (2006). https ://doi.org/10.1126/science.1122152

3. Tarascon, J.M., Armand, M.: Issues and challenges facing rechargeable lithium batteries. Nature 414, 359-367 (2001). https ://doi.org/10.1038/35104644

4. Armand, M., Tarascon, J.M.: Building better batteries. Nature 451, 652-657 (2008). https://doi.org/10.1038/451652a

5. Whittingham, M.S.: Lithium batteries and cathode materials. Chem. Rev. 104, 4271-4302 (2004). https://doi.org/10.1021/cr020 731c

6. Market Research Enging. Market analysis report, forecast 20182024. https://www.marketresearchengine.com/electric-vehiclesmarket. Accessed 8 Feb 2020

7. Research and Markets. Personal electric vehicle cars: market shares, strategies, and forecasts, worldwide, 2019-2025. https:// 
www.researchandmarkets.com/reports/4760641/personal-electricvehicle-cars-market-shares\#rela4-4539086. Accessed 8 Feb 2020

8. Liang, J.W., Li, X., Zhao, Y., et al.: An air-stable and dendrite-free $\mathrm{Li}$ anode for highly stable all-solid-state sulfide-based Li batteries. Adv. Energy Mater. 9, 1902125 (2019). https://doi.org/10.1002/ aenm. 201902125

9. Adair, K.R., Iqbal, M., Wang, C.H., et al.: Towards high performance Li metal batteries: nanoscale surface modification of 3D metal hosts for pre-stored Li metal anodes. Nano Energy 54, 375-382 (2018). https://doi.org/10.1016/j.nanoen.2018.10.002

10. Zhang, R.G., Upreti, S., Stanley Whittingham, M.: Tin-iron based nano-materials as anodes for Li-ion batteries. J. Electrochem. Soc. 158, A1498 (2011). https://doi.org/10.1149/2.108112jes

11. Wen, C.J., Huggins, R.A.: Thermodynamic study of the lithiumtin system. J. Electrochem. Soc. 128, 1181 (1981). https://doi. org/10.1149/1.2127590

12. Wang, J., Raistrick, I.D., Huggins, R.A.: Behavior of some binary lithium alloys as negative electrodes in organic solvent-based electrolytes. J. Electrochem. Soc. 133, 457 (1986). https://doi. org/10.1149/1.2108601

13. Courtney, I.A., Tse, J.S., Mao, O., et al.: Ab initio calculation of the lithium-tin voltage profile. Phys. Rev. B 58, 15583 (1998). https://doi.org/10.1103/physrevb.58.15583

14. Courtney, I.A., Dahn, J.R.: Electrochemical and in situ X-ray diffraction studies of the reaction of lithium with tin oxide composites. J. Electrochem. Soc. 144, 2045-2052 (1997). https://doi. org/10.1149/1.1837740

15. Obrovac, M.N., Chevrier, V.L.: Alloy negative electrodes for Liion batteries. Chem. Rev. 114, 11444-11502 (2014). https://doi. org/10.1021/cr500207g

16. Zhang, F., Wang, J.C., Liu, S.H., et al.: Effects of the volume changes and elastic-strain energies on the phase transition in the Li-Sn battery. J. Power Sources 330, 111-119 (2016). https://doi. org/10.1016/j.jpowsour.2016.08.136

17. Beaulieu, L.Y., Eberman, K.W., Turner, R.L., et al.: Colossal reversible volume changes in lithium alloys. Electrochem. SolidState Lett. 4, A137-A140 (2001). https://doi.org/10.1149/1.13881 78

18. Beaulieu, L.Y., Beattie, S.D., Hatchard, T.D., et al.: The electrochemical reaction of lithium with tin studied by in situ AFM. J. Electrochem. Soc. 150, A419-A424 (2003). https://doi. org/10.1149/1.1556595

19. Mukaibo, H., Momma, T., Shacham-Diamand, Y., et al.: In situ stress transition observations of electrodeposited Sn-based anode materials for lithium-ion secondary batteries. Electrochem. SolidState Lett. 10, A70-A73 (2007). https://doi.org/10.1149/1.24264 10

20. Yang, S.F., Zavalij, P.Y., Whittingham, M.S.: Anodes for lithium batteries: tin revisited. Electrochem. Commun. 5, 587-590 (2003). https://doi.org/10.1016/s1388-2481(03)00135-8

21. Idota, Y., Kubota, T., Matsufuji, A., et al.: Tin-based amorphous oxide: a high-capacity lithium-ion-storage material. Science 276, 1395-1397 (1997). https://doi.org/10.1126/science.276.5317.1395

22. Idota, Y., Mishima, M., Miyaki, Y., et al.: Nonaqueous secondary battery. U.S. Patent 5780181 (1998)

23. Courtney, I.A.: Key factors controlling the reversibility of the reaction of lithium with $\mathrm{SnO}_{2}$ and $\mathrm{Sn}_{2} \mathrm{BPO}_{6}$ glass. J. Electrochem. Soc. 144, 2943-2948 (1997). https://doi.org/10.1149/1.1837941

24. Kawakami, S., Asao, M.: Electrode material for anode of rechargeable lithium battery, electrode structural body using said electrode material, rechargeable lithium battery using said electrode structural body, process for producing said electrode structural body, and process for producing said rechargeable lithium battery. U.S. Patent 7534528B2 (2009)

25. Fan, Q., Chupas, P.J., Whittingham, M.S.: Characterization of amorphous and crystalline tin-cobalt anodes.
Electrochem. Solid-State Lett. 10, A274-A278 (2007). https:// doi.org/10.1149/1.2789418

26. Todd, A.D.W., Ferguson, P.P., Fleischauer, M.D., et al.: Tin-based materials as negative electrodes for $\mathrm{Li}$-ion batteries: combinatorial approaches and mechanical methods. Int. J. Energy Res. 34, 535-555 (2010)

27. Mao, O., Dunlap, R.A., Dahn, J.R.: Mechanically alloyed Sn$\mathrm{Fe}(-\mathrm{C})$ powders as anode materials for Li-ion batteries: I. The $\mathrm{Sn}_{2} \mathrm{Fe}-\mathrm{C}$ system. J. Electrochem. Soc. 146, 405-413 (1999). https ://doi.org/10.1149/1.1391622

28. Mao, O., Dunlap, R.A., Courtney, I.A., et al.: In situ Mössbauer effect studies of the electrochemical reaction of lithium with mechanically alloyed $\mathrm{Sn}_{2}$ Fe. J. Electrochem. Soc. 145, 4195 (1998). https://doi.org/10.1149/1.1838936

29. Nwokeke, U.G., Alcántara, R., Tirado, J.L., et al.: Electron paramagnetic resonance, X-ray diffraction, Mössbauer spectroscopy, and electrochemical studies on nanocrystalline $\mathrm{FeSn}_{2}$ obtained by reduction of salts in tetraethylene glycol. Chem. Mater. 22, 2268-2275 (2010). https://doi.org/10.1021/cm902898k

30. Dong, Z.X., Wang, Q., Zhang, R.B., et al.: Reaction mechanism of the $\mathrm{Sn}_{2} \mathrm{Fe}$ anode in lithium-ion batteries. ACS Omega 4, 2234522355 (2019). https://doi.org/10.1021/acsomega.9b02417

31. Zhang, J.J., Xia, Y.Y.: Co-Sn alloys as negative electrode materials for rechargeable lithium batteries. J. Electrochem. Soc. 153, A1466-A1471 (2006). https://doi.org/10.1149/1.2204871

32. Mao, O., Dahn, J.R.: Mechanically alloyed Sn-Fe(-C) powders as anode materials for Li-ion batteries: II. The Sn-Fe system. J. Electrochem. Soc. 146, 414-422 (1999). https://doi. org/10.1149/1.1391623

33. Wang, X.L., Han, W.Q., Chen, J., et al.: Single-crystal intermetallic $\mathrm{M}-\mathrm{Sn}(\mathrm{M}=\mathrm{Fe}, \mathrm{Cu} \mathrm{Co}, \mathrm{Ni})$ nanospheres as negative electrodes for lithium-ion batteries. ACS Appl. Mater. Interfaces 2, 1548-1551 (2010). https://doi.org/10.1021/am100218v

34. Wang, X.L., Feygenson, M., Chen, H.Y., et al.: Nanospheres of a new intermetallic $\mathrm{FeSn}_{5}$ phase: synthesis, magnetic properties and anode performance in Li-ion batteries. J. Am. Chem. Soc. 133, 11213-11219 (2011). https://doi.org/10.1021/ja202243j

35. Sun, W.M., Liu, J., Wang, H., et al.: First principles investigation of the mechanical, thermodynamic and electronic properties of $\mathrm{FeSn}_{5}$ and $\mathrm{CoSn}_{5}$ intermetallic phases under pressure. J. Korean Phys. Soc. 70, 375-381 (2017). https://doi.org/10.3938/ jkps. 70.375

36. Xin, F., Zhou, H., Yin, Q., et al.: Nanocrystal conversion-assisted design of $\mathrm{Sn}-\mathrm{Fe}$ alloy with a core-shell structure as high-performance anodes for lithium-ion batteries. ACS Omega 4, 48884895 (2019). https://doi.org/10.1021/acsomega.8b03637

37. Xin, F.X., Wang, X.L., Bai, J.M., et al.: A lithiation/delithiation mechanism of monodispersed $\mathrm{MSn}_{5}(\mathrm{M}=\mathrm{Fe}, \mathrm{Co}$ and $\mathrm{FeCo})$ nanospheres. J. Mater. Chem. A 3, 7170-7178 (2015). https://doi. org/10.1039/c4ta06960a

38. Mao, O., Dahn, J.R.: Mechanically alloyed $\mathrm{Sn}-\mathrm{Fe}(-\mathrm{C})$ powders as anode materials for Li-ion batteries: III. $\mathrm{Sn}_{2} \mathrm{Fe}$ : $\mathrm{SnFe}_{3} \mathrm{C}$ active/inactive composites. J. Electrochem. Soc. 146, 423-427 (1999). https://doi.org/10.1149/1.1391624

39. Dong, Z., Zhang, R., Ji, D., et al.: The anode challenge for lithium-ion batteries: a mechanochemically synthesized $\mathrm{Sn}$ $\mathrm{Fe}-\mathrm{C}$ composite anode surpasses graphitic carbon. Adv. Sci. 3, 1500229 (2016). https://doi.org/10.1002/advs.201500229

40. Xin, F.X., Tian, H.J., Wang, X.L., et al.: Enhanced electrochemical performance of $\mathrm{Fe}_{0.74} \mathrm{Sn}_{5} @$ reduced graphene oxide nanocomposite anodes for both $\mathrm{Li}$-ion and $\mathrm{Na}$-ion batteries. ACS Appl. Mater. Interfaces 7, 7912-7919 (2015). https://doi. org/10.1021/am508547g

41. Shi, H.X., Zhang, A.P., Zhang, X.K., et al.: Pyrolysis of cyanobridged hetero-metallic aerogels: a general route to immobilize $\mathrm{Sn}-\mathrm{M}(\mathrm{M}=\mathrm{Fe}, \mathrm{Ni})$ alloys within a carbon matrix for stable and 
fast lithium storage. Nanoscale 10, 4962-4968 (2018). https:// doi.org/10.1039/c7nr06768b

42. Shi, H., Fang, Z., Zhang, X., et al.: Double-network nanostructured hydrogel-derived ultrafine $\mathrm{Sn}-\mathrm{Fe}$ alloy in three-dimensional carbon framework for enhanced lithium storage. Nano Lett. 18, 3193-3198 (2018). https://doi.org/10.1021/acs.nanol ett. 8 b00898

43. Chang, X.H., Wang, T., Liu, Z.L., et al.: Ultrafine Sn nanocrystals in a hierarchically porous $\mathrm{N}$-doped carbon for lithium ion batteries. Nano Res. 10, 1950-1958 (2017). https://doi.org/10.1007/ s12274-016-1381-6

44. Sun, L., Ma, T.T., Zhang, J., et al.: Double-shelled hollow carbon spheres confining tin as high-performance electrodes for lithium ion batteries. Electrochim. Acta 321, 134672 (2019). https://doi. org/10.1016/j.electacta.2019.134672

45. Luo, B., Wang, B., Li, X., et al.: Graphene-confined Sn nanosheets with enhanced lithium storage capability. Adv. Mater. 24, 35383543 (2012). https://doi.org/10.1002/adma.201201173

46. Qin, J., He, C., Zhao, N., et al.: Graphene networks anchored with sn@graphene as lithium ion battery anode. ACS Nano 8, 1728-1738 (2014). https://doi.org/10.1021/nn406105n

47. Xu, Y., Liu, Q., Zhu, Y., et al.: Uniform nano-Sn/C composite anodes for lithium ion batteries. Nano Lett. 13, 470-474 (2013). https://doi.org/10.1021/nl303823k

48. Zhu, Z., Wang, S., Du, J., et al.: Ultrasmall Sn nanoparticles embedded in nitrogen-doped porous carbon as high-performance anode for lithium-ion batteries. Nano Lett. 14, 153-157 (2014). https://doi.org/10.1021/nl403631h

49. Zhou, X., Yu, L., Yu, X., et al.: Encapsulating Sn nanoparticles in amorphous carbon nanotubes for enhanced lithium storage properties. Adv. Energy Mater. 6, 1601177 (2016). https://doi. org/10.1002/aenm.201601177

50. Wu, C., Maier, J., Yu, Y.: Sn-based nanoparticles encapsulated in a porous 3D graphene network: advanced anodes for high-rate and long life Li-ion batteries. Adv. Funct. Mater. 25, 3488-3496 (2015). https://doi.org/10.1002/adfm.201500514

51. Li, X.Y., Chen, Y.M., Wang, H.T., et al.: Inserting Sn nanoparticles into the pores of $\mathrm{TiO}_{2-x}-\mathrm{C}$ nanofibers by lithiation. Adv. Funct. Mater. 26, 376-383 (2016). https://doi.org/10.1002/ adfm. 201503711

52. Zhang, H.W., Huang, X.D., Noonan, O., et al.: Tailored yolkshell Sn@C nanoboxes for high-performance lithium storage. Adv. Funct. Mater. 27, 1606023 (2017). https://doi.org/10.1002/ adfm. 201606023

53. Zhang, N., Wang, Y.Y., Jia, M., et al.: Ultrasmall Sn nanoparticles embedded in spherical hollow carbon for enhanced lithium storage properties. Chem. Commun. 54, 1205-1208 (2018). https://doi. org/10.1039/c7cc09095a

54. Ying, H.J., Zhang, S.L., Meng, Z., et al.: Ultrasmall Sn nanodots embedded inside $\mathrm{N}$-doped carbon microcages as high-performance lithium and sodium ion battery anodes. J. Mater. Chem. A 5, 8334-8342 (2017). https://doi.org/10.1039/c7ta01480e

55. Hirai, K., Ichitsubo, T., Uda, T., et al.: Effects of volume strain due to $\mathrm{Li}-\mathrm{Sn}$ compound formation on electrode potential in lithiumion batteries. Acta Mater. 56, 1539-1545 (2008)

56. Wang, J.S., Liu, P., Hicks-Garner, J., et al.: Cycle-life model for graphite-LiFePO 4 cells. J. Power Sources 196, 3942-3948 (2011). https://doi.org/10.1016/j.jpowsour.2010.11.134

57. Seo, D.M., Nguyen, C.C., Young, B.T., et al.: Characterizing solid electrolyte interphase on $\mathrm{Sn}$ anode in lithium ion battery. J. Electrochem. Soc. 162, A7091-A7095 (2015). https://doi. org/10.1149/2.0121513jes

58. Yang, Z., Gewirth, A.A., Trahey, L.: Investigation of fluoroethylene carbonate effects on tin-based lithium-ion battery electrodes. ACS Appl. Mater. Interfaces 7, 6557-6566 (2015). https://doi. org/10.1021/am508593s
59. Satoshi Mizutani, H.I., Akinori Kita, A.Y.: Anode active material and battery. U.S. Patent 20080193856A1 (2008)

60. Hong, S., Choo, M., Kwon, Y., et al.: Mechanisms for stable solid electrolyte interphase formation and improved cycling stability of tin-based battery anode in fluoroethylene carbonate-containing electrolyte. Adv. Mater. Interfaces 3, 1600172 (2016). https://doi. org/10.1002/admi.201600172

61. Li, J.Z., Li, H., Wang, Z.X., et al.: The interaction between $\mathrm{SnO}$ anode and electrolytes. J. Power Sources 81/82, 346-351 (1999)

62. Li, H., Huang, X.J., Chen, L.Q.: Direct imaging of the passivating film and microstructure of nanometer-scale $\mathrm{SnO}$ anodes in lithium rechargeable batteries. Electrochem. Solid State Lett. 1, 241-243 (1999). https://doi.org/10.1149/1.1390699

63. Li, H., Shi, L.H., Lu, W., et al.: Studies on capacity loss and capacity fading of nanosized $\mathrm{SnSb}$ alloy anode for Li-ion batteries. J. Electrochem. Soc. 148, A915-A922 (2001). https://doi. org/10.1149/1.1383070

64. Protesescu, L., Rossini, A.J., Kriegner, D., et al.: Unraveling the core-shell structure of ligand-capped $\mathrm{Sn} / \mathrm{SnO}_{x}$ nanoparticles by surface-enhanced nuclear magnetic resonance, Mössbauer, and X-ray absorption spectroscopies. ACS Nano 8, 2639-2648 (2014). https://doi.org/10.1021/nn406344n

65. Matsumura, Y., Wang, S., Mondori, J.: Interactions between disordered carbon and lithium in lithium ion rechargeable batteries. Carbon 33, 1457-1462 (1995). https://doi.org/10.1016/00086223(95)00098-X

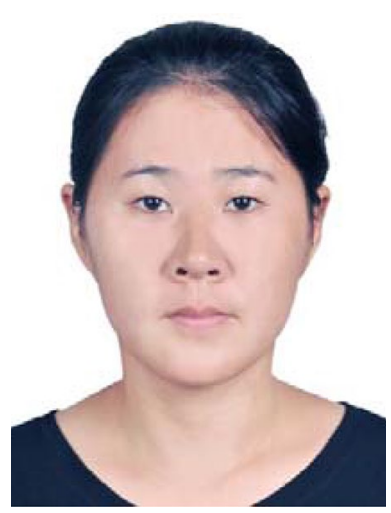

Fengxia Xin received her $\mathrm{PhD}$ from the Ningbo Institute of Materials Technology and Engineering, the Chinese Academy of Sciences. Currently, she is a postdoctoral researcher in Prof. M. Stanley Whittingham's group in Binghamton University. Her research is high-energy-density cathodes and anodes, including layered metal oxide compounds and alloy anode materials.

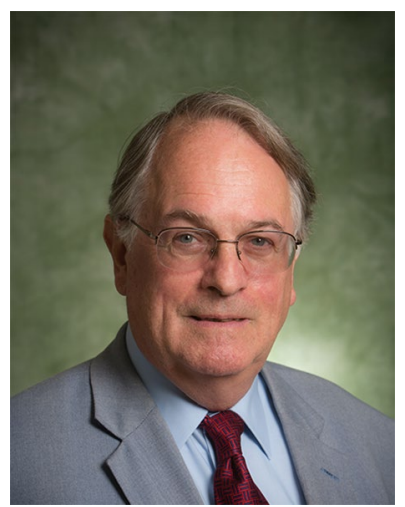

M. Stanley Whittingham received his BA and DPhil degrees in Chemistry from Oxford University, where he is now an honorary fellow of New College. Following that, he did research at Stanford University, and in 1972, he joined Exxon's Corporate Research Laboratory and discovered the role of intercalation in battery reactions. This resulted in the first commercial lithium rechargeable batteries that were built by Exxon Enterprises. In 1988, he returned to academia at Binghamton University (SUNY), where he is a SUNY distinguished professor of Chemistry and Materials Science and Engineering. In 2019, he was awarded the Chemistry Nobel Laureate. At Binghamton, he leads the NorthEast Center for Chemical Energy Storage and is a partner in the Battery500 consortium. 